\title{
Isocratic RP- HPLC Method for Simultaneous Separation and Estimation of Zofenopril and Hydrochlorthiazide in Pharmaceutical Dosage Forms
}

\author{
G.S. DEVIKA ${ }^{\S}$, M.SUDHAKAR ${ }^{\S}$, AND J.VENKATESHWARA RAO\# \\ ${ }^{\S}$ Department of Pharmaceutical Chemistry, Malla Reddy College of Pharmacy, \\ Maissamaguda, Dullapally, Secunderabad -14 Andrapradesh, India. \\ \# Department of Pharmaceutical Chemistry, Sultan Ul Uloom College of Pharmacy, Road \\ No3, Banjara Hills, Secunderabad- 500034 Andra Pradesh India.
}

E-mail address:_devikasubramaniyan@gmail.com

Received 31 October 2011; Accepted 1 February 2012

\begin{abstract}
A simple, rapid, sensitive and accurate isocratic reverse phase high performance liquid chromatographic (RP-HPLC) method has been developed and subsequently validated for the simultaneous determination of Zofenopril and Hydrochlorthiazide in combined dosage form. Chromatographic separation of the two drugs was performed on a Purospher BDS C18 column $(250 \mathrm{~mm} \times 4.6$ $\mathrm{mm}$ id, $5 \mu \mathrm{m}$ particle size). The mobile phase comprising of acetonitrile methanol: $0.02 \mathrm{M} \mathrm{NaH}_{2} \mathrm{PO}_{4}$ buffer $(40: 20: 40)$ was delivered at a flow rate of $1.0 \mathrm{~mL} / \mathrm{min}$. The $\mathrm{pH}$ of the mobile phase is adjusted to 7.2 with Sodium hydroxide solution. Detection was performed at $245 \mathrm{~nm}$. The separation was completed within 10 min and the retention time of hydrochlorthiazide is 4.62 and Zofenopril is $6.86 \mathrm{~min}$ respectively. Calibration curves were linear with $\mathrm{R}^{2}$ between $0.99-1.0$ over a concentration range of $100-600 \mu \mathrm{g} / \mathrm{ml}$ for Zofenopril calcium and $50-300 \mu \mathrm{g} / \mathrm{ml}$ for hydrochlorthiazide..The developed method was successfully applied to determine Zofenopril and hydrochlorthiazide in pharamaceutical formulations.
\end{abstract}

Key words: Zofenopril , Hydrochlorthiazide; Validation; Pharmaceutical formulations.

\section{Introduction:}

Zofenopril is an antihypertensive drug belonging to the family of a sulfhydryl angiotensin converting enzyme(ACE) inhibitors, characterized by high lipophilicity, sustained cardiac ACE inhibition, and antioxidant and tissue protective activities ${ }^{1-3}$. Zofenopril (ZOF) is chemically(4S)-N-[3-(Benzoylsulfanyl)-2(S)-methylpropionyl]-4-(phenylsulfanyl)-L-

proline $^{4-5}$ (Figure1.). Hydrochlorothiazide (HCT) is chemically 6-chloro-3,4-dihydro-2 $\mathrm{H}$ 1,2,4-benzothiadiazine-7-sulfonamide 1,1-dioxide(Figure1.) is a thiazide diuretic. Thiazides 
affect the renal tubular mechanisms of electrolyte reabsorption, directly increasing excretion of sodium and chloride in approximately equivalent amount.it is official in I.P,B.P, USP ${ }^{6-}$ ${ }^{8}$.Zofenopril $(30 \mathrm{mg})$ when combined with low dose hydrochlorthiazide $(12.5 \mathrm{mg})$ showed an additional $4-8 \mathrm{~mm} \mathrm{Hg}$ anti-hypertensive effect with favorable tolerability in line with that of other combinations of an ACE inhibitor and low dose hydrochlorthiazide ${ }^{9}$. A new combination dosage form of Zofenopril and hydrochlorthiazide is being used in treatment of hypertension ${ }^{10}$.Literature survey shows that various analytical methods have been reported for estimation of zofenopril and hydrochlorthiazie individually and combination with other drugs ${ }^{9-17}$. Only one Gradient HPLC ${ }^{18}$ method was reported for its simultaneous estimation .Isocratic elution technique is preferred for simple samples (i.e, less than two components )and it is more helpful in gradient elution instrumentation is not available in quality control laboratories. Hence, an attempt has been made to develop new isocratic RP-HPLC method for its simultaneous estimation of Zofenopril and Hydrochlorthiazide in pharmaceutical formulation with good accuracy, precision and simplicity. The developed method is validated as per ICH guidelines ${ }^{19}$.<smiles>C[C@H](CSC(=O)c1ccccc1)C(=O)N1C[C@H](Sc2ccccc2)C[C@H]1C(=O)O</smiles>

Structure of Zofenopril<smiles>NS(=O)(=O)c1cc2c(cc1Cl)NCNS2(=O)=O</smiles>

Structure of Hydrochlorthiazide

Figure 1. Structure of Zofenopril and Hydrochlorthiazide.

\section{Experimental}

\section{Equipment}

Analysis was performed on Alliance HPLC System (Water's Corporation, USA) consisting of 2695 separation module and 2998 Photo Diode Array (PDA) detector. Chromatographic data was acquired using waters empower software.

\section{Chemicals}

Zofenopril (purity $\geq 98 \%$ ) was purchased from American custom chemicals (San diego,CA, U.S.A). Hydrochlorthiazide was kindly supplied by Aurobindo pharma limited, Hyderabad, India. Acetonitrile and methanol of HPLC grade were procured from Rankem lab ltd. Sodium di hydrogen phosphate and sodium hydroxide were A.R grade purchased from Merck chemicals Mumbai, India. Water HPLC grade was obtained from a Milli-Q RO water purification system. Tablets of Zoprazide ${ }^{\circledR}$ was obtained from a commercial source.

\section{HPLC Conditions}

A Purospher BDS $\mathrm{C}_{18}(250 \mathrm{~cm} * 4.6 \mathrm{~mm}, 5 \mu)$ column was used as the stationary phase. The contents of the mobile phase were acetonitrile, methanol and $0.02 \mathrm{M} \mathrm{NaH} \mathrm{NO}_{4}$ buffer 
(adjusted to $\mathrm{pH} 7.2$ with sodium hydroxide solution) in the ratio of 40:20:40 v/v. They were filtered through $0.45 \mu \mathrm{m}$ membrane filter, sonicated for $15 \mathrm{~min}$. and pumped from the respective solvent reservoirs to the column at a flow rate of $1 \mathrm{~mL} / \mathrm{min}$. The run time was set at 10 min and column temperature was ambient. Prior to the injection of the drug solution, the column was equilibrated for at least $0.5 \mathrm{~h}$ with the mobile phase flowing through the system. The analytes were monitored at $245 \mathrm{~nm}$.

\section{Preparation of standard stock solutions and linearity solutions}

Standard stock solutions of ZOF and HCT were prepared separately by dissolving $50 \mathrm{mg}$ of each drug in $50 \mathrm{~mL}$ volumetric flask with $10 \mathrm{~mL}$ of mobile phase and the solutions were sonicated for about $15 \mathrm{~min}$. Then the volume was made up to the mark with mobile phase to get $1 \mathrm{mg} / \mathrm{mL}$ standard stock solution. Several aliquots of these standard stock solutions were taken in different $10 \mathrm{~mL}$ volumetric flask and diluted up to the mark with mobile phase such that the final linearity concentrations of zofenopril and hydrochlorthiazide were 100-600 $\mu \mathrm{g} / \mathrm{ml}$ and $50-300 \mu \mathrm{g} / \mathrm{ml}$, respectively.

\section{Assay standard solution preparation}

A working standard solution containing $300 \mu \mathrm{g} / \mathrm{ml}$ of ZOF and $125 \mu \mathrm{g} / \mathrm{ml}$ of HCT were prepared from the above standard stock solution.

\section{Preparation of sample solution}

Twenty tablets each containing $30 \mathrm{mg}$ of ZOF and $12.5 \mathrm{mg}$ of HCT were weighed and powdered equivalent to dose, transferred to a $100 \mathrm{~mL}$ volumetric flask, and extracted with mobile phase .The mixture was sonicated for $20 \mathrm{~min}$ in an ultrasonic bath. The volume was adjusted to $100 \mathrm{~mL}$ with mobile phase to get the concentration of $300 \mu \mathrm{g} / \mathrm{ml}$ of ZOF and 125 $\mu \mathrm{g} / \mathrm{mL}$ of HCT. The solution was filtered through $0.45 \mu$ nylon filter. The filtrate collected after discarding first few milliliters was injected on the above chromatographic system. All the solutions were protected from light.

\section{Method development and optimization}

Some important parameters like $\mathrm{pH}$ of the mobile phase, concentration of the acid or buffer solution, percentage and type of organic modifier, etc., were tested for a good chromatographic separation. Trails showed that a neutral mobile phase with reverse phase Purospher BDS column gives symmetric and sharp peaks. For this reason $0.02 \mathrm{M}$ sodium di hydrogen ortho phosphate buffer solution was preferred and the neutral $\mathrm{pH}$ was maintained by using $0.1 \mathrm{~N}$ sodium hydroxide solution. Acetonitrile and Methanol both were chosen as the organic modifier because both dissolves drug very well. Mobile phase composition of acetonitrile methanol: $0.02 \mathrm{M} \mathrm{NaH}_{2} \mathrm{PO}_{4}$ buffer ( 40:20:40 v/v) at flow rate of $1 \mathrm{~mL} / \mathrm{min}$ showed good resolution. When $0.1 \mathrm{~N}$ sodium hydroxide was used as modifier, resolution between $\mathrm{ZOF}$ and HCT was much better at $\mathrm{pH} 7.0$, with a decrease in peak tailing. Retention times of the drugs obtained under these conditions were is 4.62 and $6.86 \mathrm{~min}$ for HCT and ZOF, respectively.For the quantitative analytical purpose the wavelength was set at $245 \mathrm{~nm}$. The typical chromatogram of the sample is shown in Figure 2. 


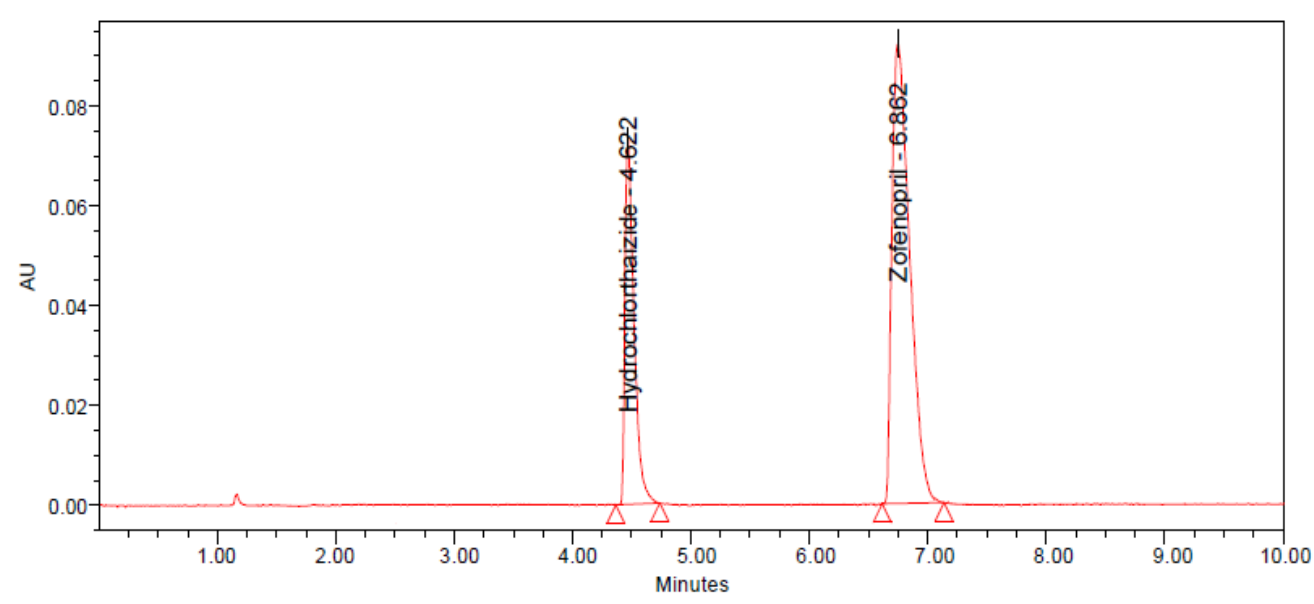

Figure 2. A Typical chromatogram of Zofenopril and Hydrochlorthiazide.

\section{Validation of the method}

\section{System suitability studies}

The column efficiency, resolution, and peak asymmetry were calculated for the standard solutions. The values obtained demonstrated the suitability of the system for the analysis of the drug combination was reported in Table 1.

Table 1.System Suitability parameters.

\begin{tabular}{|c|c|c|c|c|}
\hline S.No & Parameters & Zofenopril & Hydroclorthiazide & $\begin{array}{c}\text { Acceptance } \\
\text { criteria }\end{array}$ \\
\hline 1 & Retention time & 6.86 & 4.62 & $\begin{array}{c}\text { Not more than } \\
1.5\end{array}$ \\
\hline 2 & $\begin{array}{c}\text { Asymmetry of the } \\
\text { peak }\end{array}$ & 0.71 & 0.62 & $\begin{array}{c}\text { Not more } \\
\text { than } \%\end{array}$ \\
\hline 3 & $\begin{array}{c}\text { RSD of replicate } \\
\text { injections }\end{array}$ & 0.185 & 0.346 & $\begin{array}{c}\text { Not less than } \\
2000\end{array}$ \\
\hline 4 & $\begin{array}{c}\text { Theoretical plates } \\
\text { Resolution }\end{array}$ & 4105 & 3548 & More than 2 \\
\hline 5 & \multicolumn{2}{|c|}{3.8} & & \\
\hline
\end{tabular}

Solution stability studies

In order to demonstrate the stability of both the standard and sample solutions during analysis, both solutions were analyzed over a period of $24 \mathrm{~h}$ at room temperature. The results indicated for both the solutions, the retention time and peak area of ZOF and HCT did not show much variation (\%RSD less than 2 ). There was no significant degradation with in the indicated period. Hence it was concluded that both the solutions were stable for $24 \mathrm{~h}$ at room temperature.

\section{Specificity}

The specificity of the method was checked for the interference of impurities in the analysis of a blank solution (without any sample) and then a drug solution of $20 \mu \mathrm{g} / \mathrm{mL}$ was injected 
into the column, under optimized chromatographic conditions, to demonstrate the separation of both ZOF and HCT from any of the impurities, if present. As there was no interference of impurities and also no change in the retention time, the method was found to be specific and also confirmed with the results of analysis of formulation.

\section{Linearity study}

The peak areas of ZOF and HCT were linear with respect to the concentration over the range of $100-600 \mu \mathrm{g} / \mathrm{mL}$ and $50-300 \mu \mathrm{g} / \mathrm{mL}$, respectively. The slope and intercept value for calibration curve $\mathrm{Y}=10166 \mathrm{x}+16891(\mathrm{r}=0.999)$ for $\mathrm{ZOF}$ and $\mathrm{Y}=10498 \mathrm{x}+39334(\mathrm{r}=0.999)$ for HCT.

The results showed that an excellent correlation exists between peak area and concentration of the drugs within the concentration range indicated previously. The data was analyzed by "linear regression least squares fit,"and the parameters are listed in Table 2.

Table 2. Linearity Study.

\begin{tabular}{|c|c|c|c|}
\hline S.NO & Parameters & Zofenopril & Hydroclorthiazide \\
\hline 1 & Linearity range & $100-600 \mu \mathrm{g} / \mathrm{mL}$ & $50-300 \mu \mathrm{g} / \mathrm{mL}$ \\
\hline 2 & Slope & 10166 & 10498 \\
\hline 3 & Intercept & 16891 & 39334 \\
\hline 4 & Correlation coefficient $\left(\mathrm{r}^{2}\right)$ & 0.999 & 0.998 \\
\hline 5 & Limit of Detection & $0.51 \mu \mathrm{g} / \mathrm{mL}$ & $0.22 \mu \mathrm{g} / \mathrm{mL}$ \\
\hline 6 & Limit of Quantification & $5 \mu \mathrm{g} / \mathrm{mL}$ & $2 \mu \mathrm{g} / \mathrm{mL}$ \\
\hline
\end{tabular}

\section{Precision}

Intraday and Interday precision were evaluated by determining the corresponding responses three times on the same day and on 3 different days for $\mathrm{ZOF}(200,300,400 \mu \mathrm{g} / \mathrm{mL})$ and for $\operatorname{HCT}(100,150,200 \mu \mathrm{g} / \mathrm{mL})$. The results were reported in terms of RSD and shown in Table 3.

Table 3. Intraday and interday precision data for the quantitative determination of Zofenopril and Hydrochlorthiazide.

\begin{tabular}{|c|c|c|c|c|}
\hline \multirow{2}{*}{$\begin{array}{c}\text { Concentration } \\
\mu \mathrm{g} / \mathrm{mL}\end{array}$} & $\begin{array}{c}\text { Intraday precision } \\
\text { Calculated } \\
\text { concentration } \pm \text { SD }\end{array}$ & RSD $\%$ & $\begin{array}{c}\text { Interday precision } \\
\text { concentation } \pm \text { SD } *\end{array}$ & RSD $\%$ \\
\hline Zofenopril & $199.68 \pm 0.422$ & 0.57 & $200.14 \pm 0.091$ & 0.13 \\
\hline 200 & $299.10 \pm 0.517$ & 0.21 & $300.45 \pm 0.143$ & 0.14 \\
\hline 300 & $401.01 \pm 0.109$ & 0.79 & $400.96 \pm 0.264$ & 0.58 \\
\hline 400 & $100.28 \pm 0.347$ & 0.18 & $99.24 \pm 0.156$ & 0.63 \\
\hline Hydrochlorthiazide & $149.59 \pm 0.169$ & 0.59 & $150.24 \pm 0.106$ & 0.13 \\
\hline 100 & $200.19 \pm 0.365$ & 0.47 & $199.58 \pm 0.654$ & 0.34 \\
\hline 150 &
\end{tabular}

* Average of six determinations. 


\section{Accuracy}

To study the reliability, suitability and accuracy of the method recovery studies were carried out. A known quantity of the pure drug was added to the pre-analyzed sample formulation at the level of $50 \%, 100 \%$ and $150 \%$ and further dilutions were made and the concentration of the drugs were determined from calibration curve. Recovery studies were carried out six times and the percentage recovery was calculated and presented in Table 4. The lower value of \%RSD indicates the method is accurate. The mean recoveries were in the range of $99.15-100.96 \%$, which shows that there is no interference with excipients. The percent recoveries were calculated by using the following equation.

$$
\text { Percentage Recovery }=\frac{\mathrm{b}-\mathrm{a}}{\mathrm{c}} \times 100
$$

where,

a- The amount of drug found before the addition of standard drug.

b- The amount of drug found after the addition of the standard drug.

c- The amount of standard drug added.

\section{Limit of detection}

The limit of detection (LOD) is the smallest concentration that can be detected but not necessarily quantified as an exact value. It was calculated as $3.3 \partial / S$ as per ICH guidelines.The LOD of ZOF and HCT was found to be $0.51 \mu \mathrm{g} / \mathrm{mL}$ and $0.22 \mu \mathrm{g} / \mathrm{mL}$ respectively.

\section{Limit of quantitation}

The limit of quantitation (LOQ) is the lowest amount of analyte in the sample that can be determined with suitable precision and accuracy. It was calculated as $10 \mathrm{\partial} / \mathrm{S}$ as per ICH guidelines. The LOQ of ZOF and HCT was found to be $5 \mu \mathrm{g} / \mathrm{mL}$ and $2 \mu \mathrm{g} / \mathrm{mL}$, respectively.

Table 4. Recovery studies for spiked concentration of Zofenopril and hydrochlorthiazide.

\begin{tabular}{|c|c|c|c|c|}
\hline \multirow[t]{2}{*}{ Name of the Drug } & \multirow{2}{*}{$\begin{array}{l}\text { Level of \% } \\
\text { Recovery }\end{array}$} & \multicolumn{2}{|c|}{ Amount of standard } & \multirow{2}{*}{$\begin{array}{l}\% \\
\text { Recovery }\end{array}$} \\
\hline & & $\begin{array}{l}\text { Added } \\
\mu \mathrm{g} / \mathrm{mL}^{*}\end{array}$ & $\begin{array}{l}\text { Recovered } \\
\mu \mathrm{g} / \mathrm{mL}^{*}\end{array}$ & \\
\hline \multirow[t]{3}{*}{ Zofenopril } & 50 & 150 & 149.96 & 99.97 \\
\hline & 100 & 300 & 300.19 & 100.06 \\
\hline & 150 & 450 & 449.12 & 99.80 \\
\hline \multirow[t]{3}{*}{ Hydrochlorthiazide } & 50 & 75 & 75.19 & 100.25 \\
\hline & 100 & 150 & 150.34 & 100.22 \\
\hline & 150 & 225 & 226.3 & 100.57 \\
\hline
\end{tabular}

* Average of six determinations.

\section{Ruggedness and Robustness}

The ruggedness of the method was determined by carrying out the experiment on different instrument like Waters HPLC and Shimadzu HPLC by different operators using different 
columns of similar type like Phenomenex $\mathrm{C}_{18}$, HypersilC $\mathrm{H}_{18}$. Robustness of the method was determined by making slight changes in the experimental conditions such as the composition of the mobile phase, $\mathrm{pH}$ of the mobile phase, and flow rate of the mobile phase and the chromatographic characteristics were evaluated.

\section{Tablet studies}

The proposed method was successfully applied to the analysis of marketed products (Zoprazide ${ }^{\circledR}$ ) and the results obtained are given in Table 5 .

Table 5.Analysis of formulation.

\begin{tabular}{|l|l|l|l|l|}
\hline Drug & $\begin{array}{l}\text { Labeled } \\
\text { amount(mg) }\end{array}$ & $\begin{array}{l}\text { Amount of mg/tab } \\
\text { found* }\end{array}$ & $\begin{array}{l}\text { \%Label } \\
\text { claim }\end{array}$ & \%RD \\
\hline Zofenopril & 30 & 29.8 & 99.33 & 0.474 \\
\hline Hydrochlorthiazide & 12.5 & 12.46 & 99.68 & 0.253 \\
\hline
\end{tabular}

* Average of six determinations.

\section{Results and Discussion}

The proposed method gave good resolution between $\mathrm{ZOF}$ and HCT with in short period of time $(\leq 10 \mathrm{~min})$. The different mobile phases at various $\mathrm{pH}$ and different flow rates were examined and mobile phase with acetonitrile: methanol:0.02M $\mathrm{NaH}_{2} \mathrm{PO}_{4}$ buffer ( 40:20:40v/v)was selected as optimal mobile phase based on system suitability parameters with well resolved peaks of ZOF and HCT resolution of the peaks more than 2 . In addition high column efficiency was indicated from the large number of theoretical plates $(>3000)$. The degree of asymmetry was also evaluated using the tailing factor which did not exceed the critical value (1.5 )indicating acceptable degree of peak asymmetry. The wavelength for the detection of both compounds was $245 \mathrm{~nm}$ with best detector response. Linearity range was observed in concentration of $100-600 \mu \mathrm{g} / \mathrm{mL}$ for ZOF and 50 $300 \mu \mathrm{g} / \mathrm{mL}$ for HCT, respectively. Solution stability studies showed that the active pharmaceutical ingredients remain stable for $24 \mathrm{~h}$ at room temperature. When a known amount of pure drug solutions were added to the powder sample of tablet dosage form at three different levels and subjected to estimation of the drugs by the proposed method, there was a high recovery of ZOF and HCT, indicating that the proposed method is highly accurate. The intra-day and inter -day variations of the method was studied on the same day and on three different days and observed low \%RSD less than 1 . This shows that the present HPLC method is highly precise. The tablets were found to contain 99.92 to $100.07 \%$ of ZOF and 99.92 to $99.98 \%$ of HCT. The limit of detection and limit of quantification for ZOF was found to be 0.51 and $5 \mu \mathrm{g} / \mathrm{mL}$ respectively and for HCT, 0.22 and $2 \mu \mathrm{g} / \mathrm{mL}$ respectively, which suggests that nanogram quantity of drugs, can be estimated accurately. The changes in flow rate, $\mathrm{pH}$ of mobile phase, composition of mobile phase did not affect the percentage assay of drug confirming the robustness of the method. Ruggedness of the method was confirmed as no significant changes were observed on analysis using different instrument and different analyst. The proposed method was found to 
be Specific as there is no interference of impurities and Peak purity values for peaks of both ZOF and HCT confirmed the specificity.

\section{Conclusion}

The RP-HPLC method developed for simultaneous analysis of ZOF and HCT can be used for routine quality control of their bulk drug mixture and their combined dosage form.

\section{References}

1. Pasini AF, Garbin U and Nava MC, Am j hypertens,2007,20,443-450.

2. R. Ferrari, A.Caargnoni, S.Curello, C.Ceconi, A.Boraso and O.Visioli. J.Cardiovasc.Pharmacol.1992,20, 694-704.

3 .Evangelista Sand Manzini S,J Int Med Res.2005,33,42-54.

4. J.G.Kelly and K.O.Malley,Clin.Pharmacokinet.1990,19,177-196.

5. Ambrosioni E .Am J Cardiovasc Drugs ,2007, 7 (1): 17-24.

6. Indian Pharmacopoeia,2007; Vol. II Published by the Government of India, Ministry of Health and Family Welfare, the Indian Pharmacopoeia Commission, New Delhi: 11941196.

7. British Pharmacopoeia, 1993;Vol. II, Department of health and social services for Northern Ireland, London: stationary publication: 330

8. United States Pharmacopoeia, (USP23), 2009 National Formulary, Asian Edition, Rockville, MD: United States Pharmacopoeial Convention:2566-2568.

9. Parati G, Omboni Sand Malacco E Blood press,2006,15,7-17.

10. A.Zanchetti,G.Parati and E. Malacco,Drugs,2006,66,1107-1115.

11.Yuan jiang, Fang Yan,Bin DiLili Huang and Juan Lu, J Pharm and Biomed Analysis, 2011,55,527-532.

12. M.Jernal,E.Ivaskiv and D.Teitz.J.Chromatogr.1998,428,81-92.

13. Croo F, Van den De, Bossche W, Moerloose PD. Chromatographia ,1985,20:477-81

14. Valizadeh H, Zakeri MP, Islambulchilar Z and Tajerzadeh H. J AOAC Int,2006, 89:8893.

15. Baing MM, Vaidya VV, Sane RT, Menon SN, Dalvi K. Chromatographia ,2006,64,2936.

16. Erk N, Nartal M. Analytical letters, 1999,32,1131-41.

17. Satana E, Altinay S, Goger NG, Ozkan SAand Senturk ,J Pharm Biomed Anal, 2001,25,1009-13.

18. Serap Saglik aslan.J chromatographic science,2011,49,259-263.

19. ICH Harmonized Tripartite guideline: Validation of analytical procedures text and Methadology,2005,Q2(R1). 


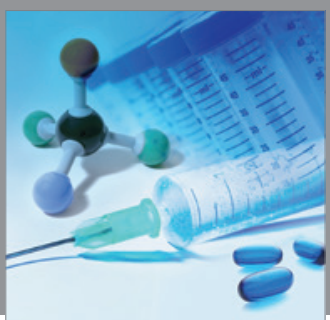

International Journal of

Medicinal Chemistry

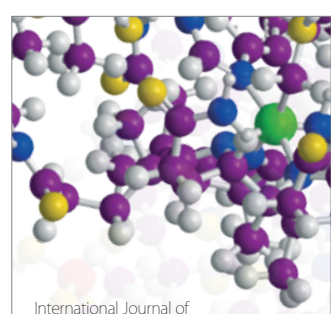

Carbohydrate Chemistry

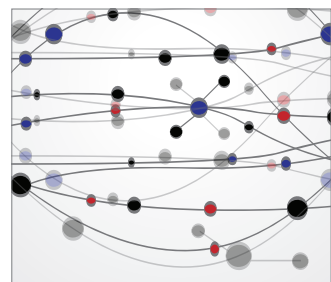

The Scientific World Journal
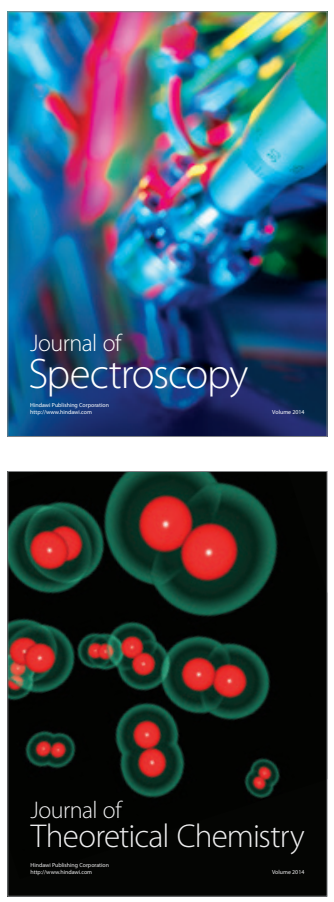
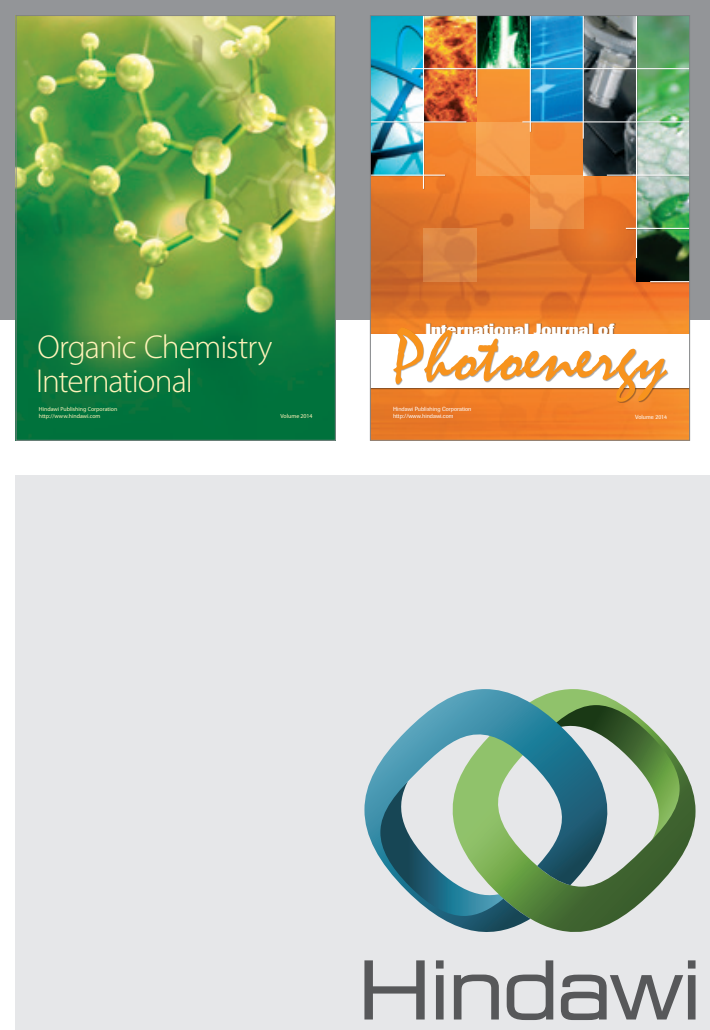

Submit your manuscripts at

http://www.hindawi.com
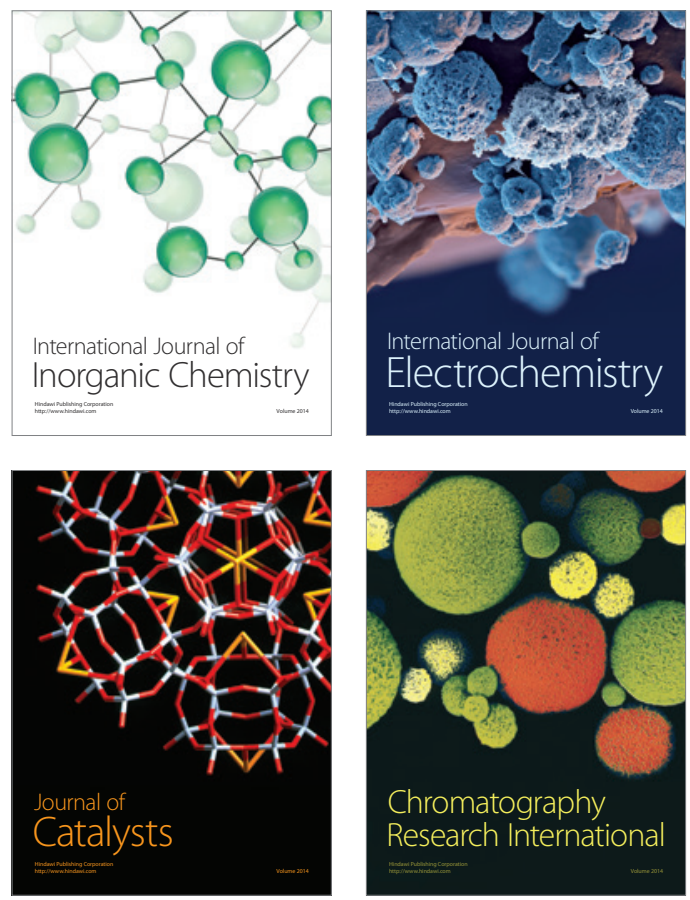
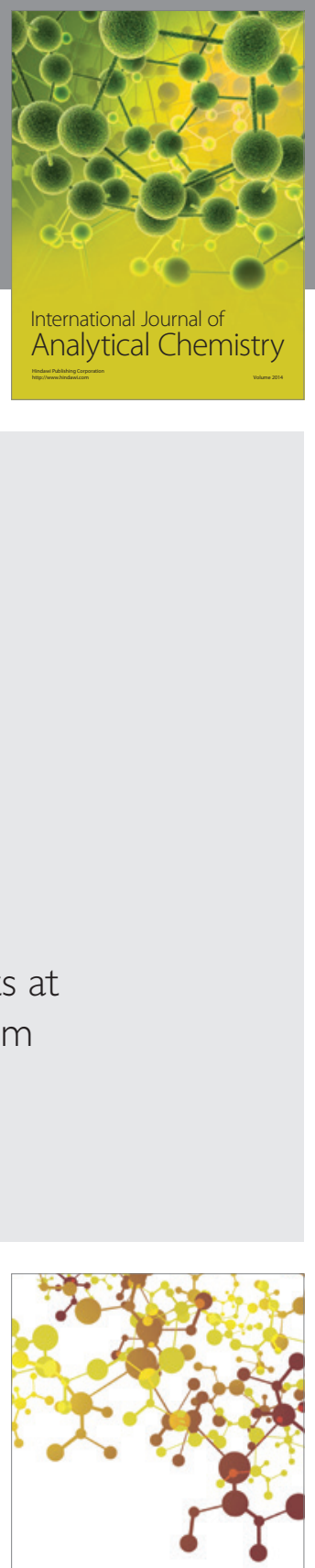

Journal of

Applied Chemistry
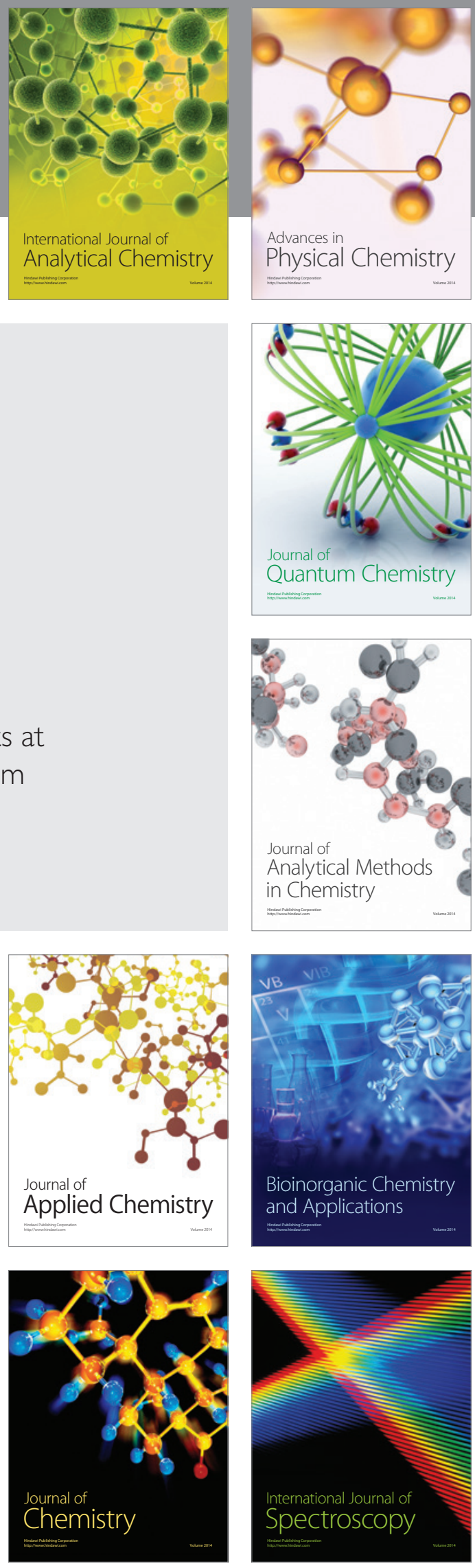